\title{
Evaluation of Entomopathogenic Fungi against Coffee Antestia Bug, (Antestiopsis Intricate) Under Laboratory Condition at Jimma
}

\author{
Tamiru Shimales*, Belay Abate, Sisay Kidanu, Demelash Tefari \\ Jimma Agricultural Research Center, Jimma, Ethiopia
}

*Corresponding Author: Tamiru Shimales, Jimma Agricultural Research Center, Jimma, Ethiopia

\begin{abstract}
Coffee is an evergreen perennial crop grown in ecosystems, which favors insect pest to survive from year to year. Antestiopsis intricate is the number one coffee insect pest in Ethiopia and highly reduce the yield and coffee quality. The uses of bio-control agents are considered suitable alternatives to the use of chemical pesticides and the current demand for biological control products. As alternative antestia bug control two entomopathenic fungi was evaluated to know the effectiveness of these bio-control agents against this pest under laboratory condition. Greater than $65 \%$ mean mortality of antestia bugs were recorded by all tested isolates with both concentrations.
\end{abstract}

Keywords: Entomopathogenic fungi, Coffee and Antestiopsis intricate

\section{INTRODUCTION}

Coffee is an evergreen perennial crop grown in ecosystems, which favours insect pest to survive from year to year (Wrighley, 1988). Insect pests are among the number of factors considered to limit coffee production and productivity. Among the coffee berry damaging insects, Antestia bug cause up to $9 \%$ yield loss and $48 \%$ coffee bean darkening (Million, 1988).

The uses of bio-control agents are considered suitable alternatives to the use of chemical pesticides and the current demand for biological control products has arisen in large part because of problems that has developed from the use of chemical pesticides (Dhaliwal and Koul, 2007). Of the various biocontrol agents considered, the entomopathogenic fungus, Metarhizium anisopliae and Beauveria bassiana have received considerable attentions as a viable alternative to chemical pesticides.

But there is no sufficient recent information about the efficacy of entomopathogenic fungi against antestia bug under laboratory and field conditions, in Ethiopia the effectiveness of different isolation of EP fungi against antestia bug is very important as one component of integrated pest management; therefore, this experiment was initiated with the objective of evaluating the efficacy of entomopathogenic fungi against Antesita intricata under laboratory condition.

\section{MATERIALS AND METHODS}

\subsection{Antestia Bug Collection and Mass Rearing}

Adult coffee Antestia intricata was collected from Metu agricultural research sub- center. The bug collection action was done in the morning because they do not like high temperature and light from the sun and hidden in coffee canopy and difficult to collect and gain enough numbers. The collection was done by hands carefully to avoid that they may be killed. The collected bugs were put in appropriate containers (transparent bottles and perforated), and immature coffee berries were put in it in order to procure food to them.

Then after reared in Jimma agricultural research center (JARC) entomology laboratory in a glass cages $\left(20.5 \times 26.7 \times 7.6 \mathrm{~cm}^{3}\right)$ covered with nylon mesh and providing fresh coffee twigs with large green berries for the insects at two day intervals. Fresh coffee twigs were added to cylindrical cages as feed for antestia bugs ,then the top parts of cages were covered with nylon mesh that allows air ventilation in and out easily but preventing the escape of the insect(fig below) 

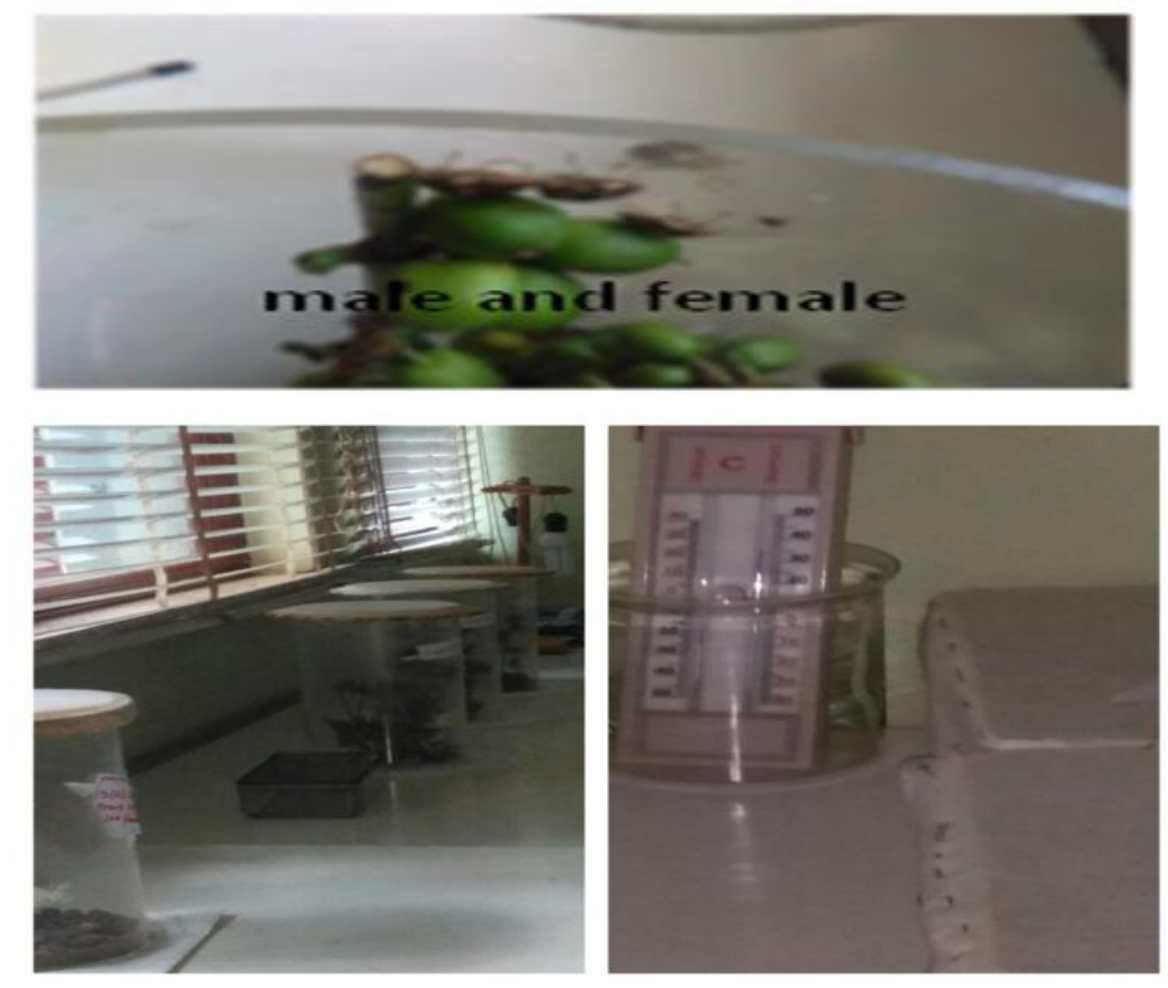

Fig1. Antestia reared and spores applied at Jimma agricultural research center, entomology laboratory

\subsection{Source, Preparation of Spore Suspension and Spraying Method}

Two cultured and mass reared isolates of fungal species; M. anspolium and B.bassiana used for antestia bug control in this experiment were obtained from nation Ambo plant protection research center.

The viability of spore of the fungi which collected from Ambo plant protection was checked in JARC pathology laboratory using binocular compound microscope. The concentrated fungal spore were diluted with sterile distilled water to make the spore suspension ready to be counted and $0.05 \%$ of tween 80 was added to the spore suspension to evenly distribute. The conidia suspensions and the suspension were stirred with magnetic stirrer for 4-5minute and the suspensions were filtered through sterile muslin cloth to eliminate the debris medium. The spore suspension of $1 \times 10^{7}$ and $1 \times 10^{8}$ conidia per $\mathrm{ml}$ of distilled water were prepared for each isolates by counting with haemocytometer.

The fungal isolates were sprayed by hand by using syringe and sprayed with equal quantity in each rectangular box containing these bugs needed to be sprayed and sure that the isolated fungi touch on them. The coffee berries were sprayed too.

\subsection{Experimental Design and Treatments}

There were seven treatments replicated three times and laid out in completely randomized design (CRD) and one control (sterile $\mathrm{H} 2 \mathrm{O}$ ) was used under the same conditions as the experimental group for comparison. Each isolates was tested at two concentrations $\left(1 \times 10^{7}\right.$ and $\left.1 \times 10^{8}\right)$. The treatments used were as follows;

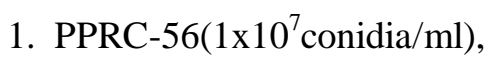

2. PPRC-56( $1 \times 10^{8}$ conidia/ml $)$

3. PPRC-2( $1 \times 10^{7}$ conidia $\left./ \mathrm{ml}\right)$

4. PPRC-2( $1 \times 10^{8}$ conidia/ml $)$

5. $\mathrm{MM}\left(1 \times 10^{7}\right.$ conidia/ml $)$ and

6. $\mathrm{MM}\left(1 \times 10^{8}\right.$ conidia/ml $)$

7. Control (Distilled $\mathrm{H} 2 \mathrm{O}$ ) repeated three times

International Journal of Research Studies in Biosciences (IJRSB) 


\subsection{Mortality of Antestia Intricata Due to Entomopathogenic Fungi}

To test the efficacy of each of the fungal isolates on insects, fifth instars (nearly adults) of bugs were placed in a rectangular plastic box and sprayed with the spore solutions. To determine how many Antestia intricata were died without being infested by applied fungi, a control group was sprayed with only sterile water as control.

Died insect/s was counted and then transferred into a Petri dish lined with moistened filter paper and mortality due to fungi was confirmed by binocular compound microscope examination of hyphae and conidia on the surface of the dead insect (Fig. 1) in JARC pathology laboratory. The efficacy was evaluated on a daily basis for twenty days, by counting died insect which were later converted to the percent mortality. Mortality data were corrected for the corresponding control mortality by Abbott (1925) formula; CM $(\%)=(\mathrm{T} \%)-\mathrm{C}(\%) / 100-\mathrm{C}(\%) * 100$

-Where, $\mathrm{CM}$ is corrected mortality, $\mathrm{T}$ is mortality in treated insects and $\mathrm{C}$ is mortality in untreated insects (Abbott, 1925).

\subsection{Data Analysis}

All data were subjected to the analysis of variance (ANOVA) with the appropriate design as per Gomez and Gomez (1984) using SAS version 9.0 computer software program (SAS, 2002). Mean separation was performed when means were significant using Least Significant Difference (LSD) at 5 $\%$ and $1 \%$ level of probability.

\section{RESULTS AND DISCUSSION}

Three entomopathogenic fungi isolates (from Beavaria bassiana, PPRC-56 and from Metarhzium anisopleae PPRC-2 and MM) were evaluated at different concentrations (1x107 and 1x108) rates against coffee antestia bug, which is one the major insect pest in the country. The analysis result showed that all isolates at both concentrations showed significant difference in mortality efficacy compared to check. The mortality of Antestia bug on $11^{\text {th }}$ day of application was not significantly different among treatments. Based on the result on $15^{\text {th }}$ day, PPRC-56 and PPRC-2 (both at $1 \times 10^{8}$ ) showed greater mortality 92.59 and $85.93 \%$ respectively than others. All isolates causing more than $95 \%$ of mortality on $17^{\text {th }}$ days of application. (table1).

Table1. Mean percent mortality of Antestia bug over days

\begin{tabular}{|c|c|c|c|c|c|c|c|c|c|c|c|}
\hline \multirow[t]{2}{*}{ Isolates } & \multirow[t]{2}{*}{ Conidia/ml } & \multicolumn{10}{|c|}{ Time after Treatment Application (Days) } \\
\hline & & \begin{tabular}{|l|}
11 \\
day
\end{tabular} & 12 day & 13 day & 14 day & 15 day & 16 day & 17 day & 18 day & 19 day & $20 \mathrm{~d}$ \\
\hline \multirow[b]{2}{*}{ PPRC-56 } & $1 \times 10^{7)}$ & $13.3 \mathrm{a}$ & 23.33abc & $36.67 \mathrm{bc}$ & $55.18 \mathrm{bc}$ & $72.22 \mathrm{bc}$ & $89.63 \mathrm{ab}$ & $96.67 \mathrm{a}$ & $96.30 \mathrm{a}$ & $100 \mathrm{a}$ & $100 \mathrm{a}$ \\
\hline & $1 \times 10^{8}$ & $10.0 \mathrm{a}$ & $30.00 \mathrm{a}$ & $46.67 \mathrm{a}$ & $75.55 \mathrm{a}$ & $92.59 \mathrm{a}$ & $100 \mathrm{a}$ & $100 \mathrm{a}$ & $100 \mathrm{a}$ & $100 \mathrm{a}$ & $100 \mathrm{a}$ \\
\hline \multirow[b]{2}{*}{ MM } & $1 \times 10^{7}$ & $13.3 \mathrm{a}$ & $23.33 \mathrm{abc}$ & $36.66 \mathrm{bc}$ & $55.18 \mathrm{bc}$ & $75.55 \mathrm{bc}$ & $86.30 \mathrm{~b}$ & $96.30 \mathrm{a}$ & $100 \mathrm{a}$ & $100 \mathrm{a}$ & $100 \mathrm{a}$ \\
\hline & $1 \times 10^{8}$ & $10.0 \mathrm{a}$ & $26.67 \mathrm{ab}$ & $36.66 \mathrm{bc}$ & $51.48 \mathrm{bc}$ & $72.22 \mathrm{bc}$ & $89.26 \mathrm{ab}$ & $100 \mathrm{a}$ & $100 \mathrm{a}$ & $100 \mathrm{a}$ & $100 \mathrm{a}$ \\
\hline \multirow[b]{2}{*}{ PPRC-2 } & $1 \times 10^{7}$ & $10.0 \mathrm{a}$ & $16.67 \mathrm{c}$ & $30.00 \mathrm{c}$ & $44.44 \mathrm{c}$ & $68.89 \mathrm{c}$ & $89.63 \mathrm{ab}$ & $96.67 \mathrm{a}$ & 10 & $100 \mathrm{a}$ & $100 \mathrm{a}$ \\
\hline & $1 \times 10^{8}$ & $10.0 \mathrm{a}$ & $20.00 \mathrm{bc}$ & 43.33ab & $61.85 \mathrm{~b}$ & $85.93 \mathrm{ab}$ & & 100 & 10 & $100 \mathrm{a}$ & $100 \mathrm{a}$ \\
\hline Control & $\left(\mathrm{DH}_{2} \mathrm{O}\right)$ & $0.00 \mathrm{~b}$ & $0.00(0 . \mathrm{d}$ & $0.00 \mathrm{~d}$ & $3.33 \mathrm{~d}$ & $3.33 \mathrm{~d}$ & $3.33 c$ & 3.3 & $6.67 \mathrm{~b}$ & $6.67 \mathrm{~b}$ & $6.67 \mathrm{~b}$ \\
\hline Mean & & 9.51 & 20.00 & 32.86 & 49 & 67.25 & 79.74 & 84. & 86.14 & 86.67 & 86.67 \\
\hline $\mathrm{LSD}(0$ & & 5.4 & 7.64 & 8.5 & 12.42 & 16.30 & 13.04 & 13.62 & 5.71 & 3.82 & 3.82 \\
\hline $\begin{array}{l}\mathrm{CV}(\%) \\
\end{array}$ & & 32.40 & 21.82 & 14.85 & 14.31 & 13.84 & 9.33 & 5.30 & 3.78 & 2.52 & 2.51 \\
\hline
\end{tabular}

Means followed by the same letters are not significantly different $(p<0.05) . \mathrm{DH}_{2} \mathrm{O}=$ distilled water

The analyzed results from the above table indicated applied fungal isolates were the most effective isolates for the control of coffee Antestia intricate under laboratory condition and produced mortality rates up to $85 \%$ after sixty day of application as compared to untreated control (distilled water sprayed) (table1). This result is correlated with the finding of Wraight and Ramos (2002), a good control means statistically significant reductions in pest numbers or damage of $75 \%$ or more, compared to an untreated control for coffee antestia bugs, Antestiopsis lineaticolis. Greater than 65\% mean of antestia bugs were died by all tested isolates with both concentrations under laboratory condition (graph 1). 
Evaluation of Entomopathogenic Fungi against Coffee Antestia Bug, (Antestiopsis Intricate) Under Laboratory Condition at Jimma
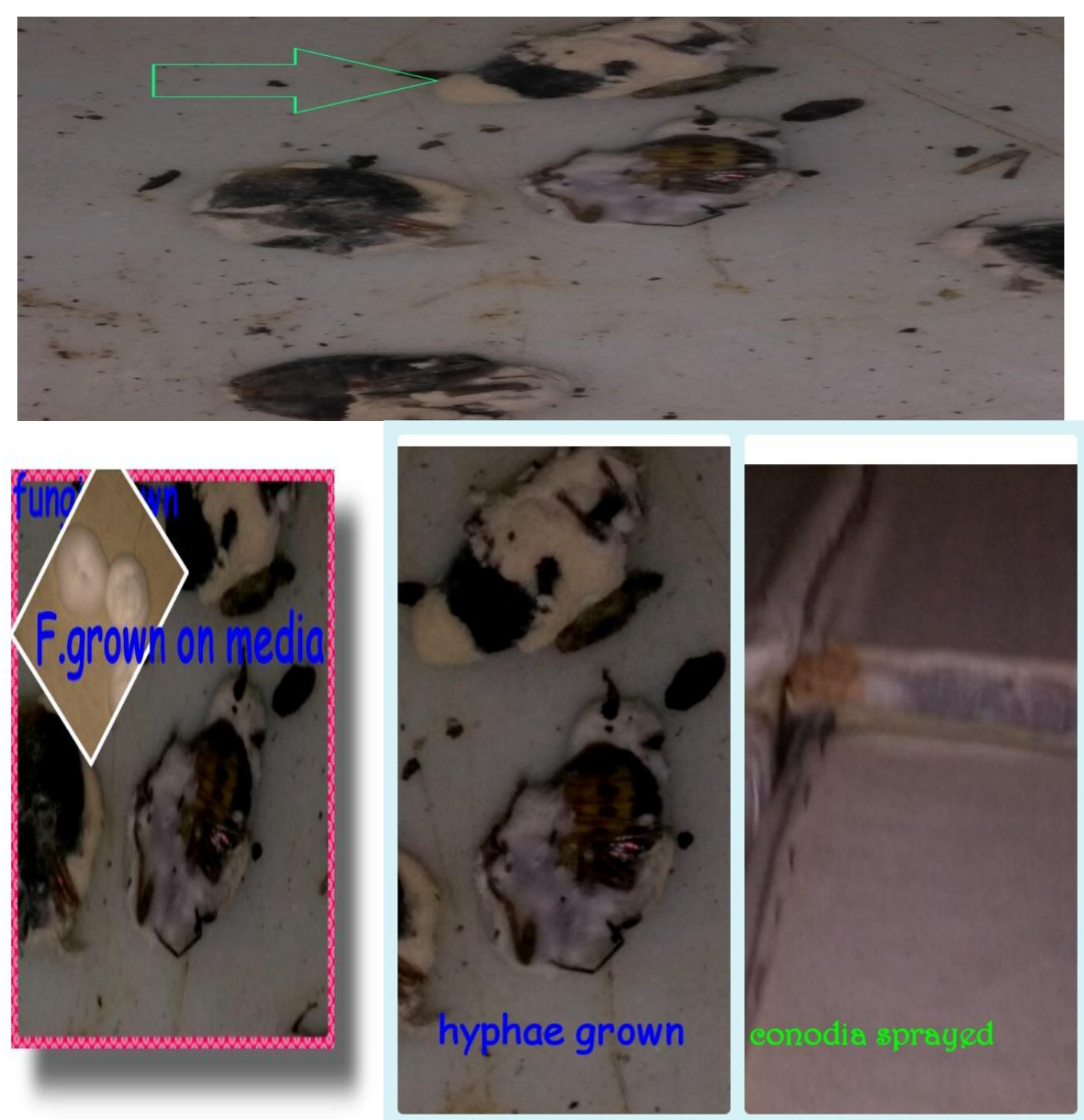

Fig1. Died antestia bugs due to EPF isolates

Result from laboratory (JARC) has shown that PPRC-56 and PPRC-2 can control above $70 \%$ mortality of antestuia bug within twenty days in higher concentration $1 \times 10^{8}$ conidia per $\mathrm{ml}$ which means that it reduces significantly Antestiopsis intricata population under lab condition. Many reports are available showing that the isolates cause a high mortality on other insects (Kannan etal., 2008). In this experiment it has been shown that all the isolates are effective against Antestiopsis intricata under laboratory condition.

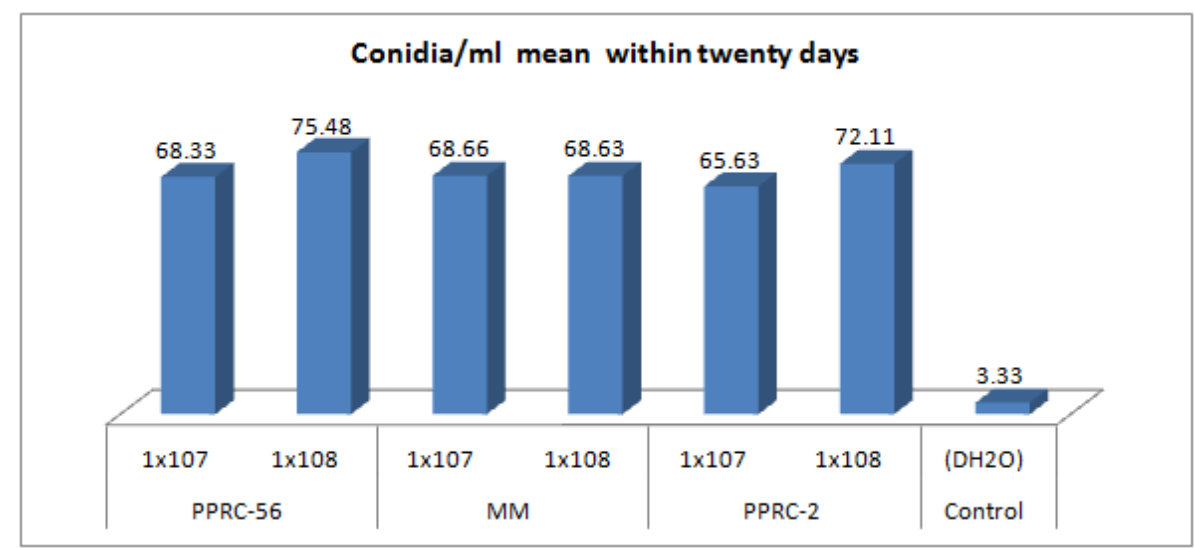

Graph1. The overall mean percent mortality $\boldsymbol{V}$ s the day after application 
Beavaria bassiana, PPRC-56 isolate kill antestia (75.48\%) than Metarhzium anisopleae PPRC-2 (72.11\%) and $\mathrm{MM}(68.63 \%)$ at $1 \times 10^{8}$ concentrations. Based on this preliminary result effect of EPF isolates has the potential to kill the coffee antestia bug more effectively as compared to check (graph1) and could be used as one of integrated pest management component.

\section{CONCLUSION AND RECOMMENDATIONS}

EPF is an important natural biological control agent of antestia bug that significantly reduce Antestia intricate under lab condition and could be used as one component of integrated pest management (IPM) after evaluated at field condition. This result calls for further investigation to verify the experiment on different stages of same insect (eggs, nymph and even adults) also with these and other bio agents should be studied .Future research should be concentrated on the field evaluation and formulation of evaluated entomopathogenic fungi development for bio pesticides.

\section{ACKNOWLEDGEMENTS}

We acknowledge the financial and technical supports provided by the Ethiopian Institute of Agriculture research for the completion of this study. We are also indebted to thank Ambo plant protection research center, for providing the tasted entomopathogenic isolates.

\section{REFERENCES}

Abbott, W. S. 1925. A method of computing the effectiveness of an insecticide. J. Econ. Entomol. 18: 265-267.

Dhaliwal, G.S. and Koul, O. (2007) Biopesticides and Pest Management: Conventional and Biotechnological Approaches. Kalyani Publishers, New Delhi.

Gomez, KA and AA Gomez. 1984. Statistical Proceduers for Agricultural Research. Second edition, John Wiley and Sons Inc. Toronto. 680p.

Kannan ,S.K. Murugan ,.A.N. Kumar ,N.Ramasubramanian and P.Methiyazhagan, 2008.Adulticidal effect of fungal pathogen, Metarizium anisoplie on malarial vector Anophles stephensi.Afr.J.Biotchnol.,7:838-841.

Million, A. 1988. Coffee bean darkening (discoloration), a new and unidentified problem on coffee, IAR Newsletter 3: 4-5.

Wraight, S.P. and M. E. Ramos. 2002. Application factors affecting the field efficacy of Beauvaria bassiana foliar treatments against the Colorado Potato Beetle Leptinotarsa decemlineata. Biological Control. 23(2):164-178.

Wrigley G (1988).coffee: Tropical Agricultural Series. Longman Scientific and John Willey and Sons, Inc., New York. 639pp

Citation: T. Shimales et al., "Evaluation of Entomopathogenic Fungi against Coffee Antestia Bug, (Antestiopsis Intricate) Under Laboratory Condition at Jimma", International Journal of Research Studies in Biosciences (IJRSB), vol. 5, no. 11, pp. 26-30, 2017. http://dx.doi.org/10.20431/2349-0365.0511005

Copyright: (1) 2017 Authors. This is an open-access article distributed under the terms of the Creative Commons Attribution License, which permits unrestricted use, distribution, and reproduction in any medium, provided the original author and source are credited. 